\title{
Applying of Patterns of Strength Training and Running Up Stairs with Interval Training Methods to Improve Futsal Player Fitness
}

\author{
Dikdik Zafar Sidik*, Asep Sumpena, Iman Imanudin \\ Fakultas Pendidikan Olahraga dan Kesehatan \\ Universitas Pendidikan Indonesia \\ Bandung, Indonesia \\ *dikdikzafarsidik@upi.edu
}

\begin{abstract}
This research is aimed at knowing the impact of running stairs to the improvement of anaerobic capacity which in this research consists of the ability of movement speed and agility, Power, and the aerobic capacity. Method used to obtain data and goals to be achieved is the experimental method, by the design of one - group pretest and posttest, by giving the treatment to the women students of Student Futsal Sports Activity Unit in the amount of 14 . The result of research shows that (1) The implementation of running stairs doesn't give the significant impact to the improvement of anaerobic dynamic capacity, (1.a) The implementation of running stairs doesn't give the significant impact to the improvement of the ability of movement speed (speed). (1.b) The implementation of running stairs doesn't give the significant impact to the improvement of the ability of movement speed (agility). (1.c) The implementation of running stairs doesn't give the significant impact to the improvement of "power" capacity, (1.d) The implementation of running stairs does not give the significant impact to the improvement of "power endurance" capacity, and (2) The implementation of running stairs give the significant impact to the improvement of dynamic aerobic capacity.
\end{abstract}

Keywords-the anaerobic capacity; the aerobic capacity; running stairs

\section{INTRODUCTION}

Futsal is the indoor version of soccer that is officially sanctioned by soccer's international governing body (FIFA). Futsal is played between 2 teams of 5 players, 1 of whom is the goalkeeper (4 outfield players) [1]. Each team may have 7 substitutes (6 outfield players and 1 goalkeeper), and unlimited substitutions may be made during an official competition. This indoor small-sided version of soccer is played on a $40 \times 20 \mathrm{~m}$ (length per width, respectively) indoor court with $3 \times 2 \mathrm{~m}$ goals. The match lasts 2 equal periods of 20 minutes, but, like basketball, the clock is stopped for some events (fouls, out of play ball, etc.) [1]. This means that match durations 75 to $85 \%$ longer than 40 minutes be expected [1]. Teams are allowed to request a time-out of 1 minute during each half, and halves are separated by a 10-minute break. During official competitions futsal is played with a smaller ball with less bounce than a typical soccer ball. Each match is officiated by 2 referees and a lines man. Futsal is played at recreational, amateur, and professional level and male and female championships are contested all over the world [1]. Since 1989 every 4 years a World Championship is contested by 16 national teams. In futsal the emphasis is on improvisation, creativity, and technique [1]. Despite its popularity [1], futsal has been only rarely the object of scientific investigations. Furthermore, the papers available in the international literature only addressed game analysis or the physiological demands of small-sided versions of soccer played at recreational level [1,2]. Match analysis and heart rate monitoring showed that futsal is an intermittent high-intensity game possibly placing important demands on the aerobic and anaerobic pathway [1]. Recently the use of small-sided games (mainly 5 vs. 5) proved to be a valid training method to improve aerobic fitness in soccer [3]. Thus, professional futsal players may possess a well-developed aerobic fitness as a consequence of training and game participation.

The physiological role in physical training in the achievements of athletes in today's sport is very visible. This is of course due to the higher level of competition so that the demands for training needs are also getting higher. One method that can be applied in physical training is the Interval training method. This method of interval training is a method that trainers often do, but in principle there are still many errors in implementation. The most important thing in applying this method is the period of recovery or rest between repetitions so that the meaningfulness of the training method becomes more effective [4].

Climbing stairs or running stairs are a form of exercise that is inexpensive, inconspicuous, and easily accessible which is associated with a decrease in mortality in the population [5]. Regardless of these characteristics, climbing stairs or running stairs as a sports modality for women has been a relatively small subject of study Bassett et al. [6] and Loy et al. [7] and only one Ilmarinen, who research climbing stairs in daily lifestyle settings [8]. In addition, only one experimental study to date Leon et al., who have examined potential health benefits, such as better blood lipid profiles, which may increase from regular ascent stairs, and no studies have examined these benefits in the female population [9]. 
Climbing stairs or running stairs also provide an ideal model to test the effects of accumulated short attacks of exercise throughout the day. Relatively little is known about benefit accumulation [10,11], and from studies conducted to date $[12,13]$, no one has examined several active activity attacks that lasted only a few minutes, which are characteristic of running stairs in an everyday setting.

\section{MethodS}

In this study using the experimental method with the form of the One-Group Pretest-Posttest design [14], which is to describe a group that is treated, but before being given the pretest treatment. Thus the results of treatment can be known to be more accurate, because it can be compared with the situation before being treated.

The study population was all futsal athletes members of the women students of Student Futsal Sports Activity Unit, Universitas Pendidikan Indonesia. Regarding the sampling technique, it was used purposively because the problems found and the variables to be examined were conditional so that the chosen participants were professional futsal players who were members of the UPI Futsal Club who participated in the 2018 Indonesian Futsal Professional League, 14 players.

In the implementation, the researcher carried out the pre test and measurement then gave exercise treatment with Interval training method with running stair, after the training was done, the post test and measurement conducted. These are the steps to collect the data, including prepared the instrument, conducted the test, and measured according to the procedure done by several tester personnel (4 people who are experts in data retrieval). The collected data is quantitative data. The schedule of data collection consists of 2 steps; the first step is pretest to reveal the initial subject's condition, the second step is posttest to observe the improvement of exercise treatment result.

The method used was experiment one group pretest-posttest design [14]. Research Instrument used to conduct the process and collect the data of Tabata protocol training program in form of weight training exercise and several test items to find out the Anaerobe and Aerobe ability, these include:

- Aerob capacity measured through Bleep Test [15].

- Anaerob capacity consists of some tests as follows:

- Velocity in the form of Agility: shuttle run $4 \mathrm{~m}$ x 5 rep [16].

- Foot Power: test 3 Hop [17]

- Power Endurance: Multi stage hurdle jump test [18].

\section{Statistical ANALYSIS AND RESUlts}

In this section, the description of processed test and measurement data is presented so that it obtains the average value, standard deviation, and Combined standard deviation (variance) in each component of anaerobic capacity and aerobic capacity in the pre-test and post-test. as stated in the following tables below.

These values will then be used to carry out tests in order to find meaning (significance) of each treatment given through the $\mathrm{t}$ test

The following are the results of the initial test and final test:

TABLE I. PAIRED SAMPLES STATISTICS

\begin{tabular}{|c|l|c|c|c|c|}
\hline \multicolumn{2}{|l|}{} & Mean & N & $\begin{array}{c}\text { Std. } \\
\text { Deviation }\end{array}$ & $\begin{array}{c}\text { Std. Error } \\
\text { Mean }\end{array}$ \\
\hline Pair 1 & Agility T2 & 50.2692 & 13 & 3.33926 & .92614 \\
\hline & Agility T1 & 50.0385 & 13 & 2.42574 & .67278 \\
\hline Pair 2 & Power T2 & 5.4346 & 13 & .31845 & .08832 \\
\hline & Power T1 & 5.5038 & 13 & .42986 & .11922 \\
\hline Pair 3 & Power Endurance T2 & 118.4167 & 12 & 10.88333 & 3.14175 \\
\hline & Power Endurance T1 & 115.2500 & 12 & 10.31438 & 2.97750 \\
\hline Pair 4 & Aerobic T2 & 44.2692 & 13 & 3.23249 & .89653 \\
\hline & Aerobic T1 & 42.9615 & 13 & 4.00053 & 1.10955 \\
\hline
\end{tabular}

TABLE II. PAIRED SAMPLES TEST

\begin{tabular}{|c|c|c|c|c|c|c|c|c|c|}
\hline & \multicolumn{5}{|c|}{ Paired Differences } & \multirow{3}{*}{$\mathbf{t}$} & \multirow{3}{*}{ Df } & \multirow{3}{*}{$\begin{array}{l}\text { Sig. }(2- \\
\text { failed) }\end{array}$} \\
\hline & & \multirow[b]{2}{*}{ Mean } & \multirow{2}{*}{$\begin{array}{c}\text { Std. } \\
\text { Deviation }\end{array}$} & \multirow{2}{*}{$\begin{array}{l}\text { Std. Error } \\
\text { Mean }\end{array}$} & \multicolumn{2}{|c|}{$\begin{array}{c}\mathbf{9 5 \%} \text { Confidence Interval of } \\
\text { The Difference }\end{array}$} & & & \\
\hline & & & & & Lower & Upper & & & \\
\hline Pair 1 & Agility T2 - Agility T1 & .23077 & 2.21223 & .61356 & -1.10607 & 1.56761 & .376 & 12 & .713 \\
\hline Pair 2 & Power T2 - Power T1 & -.06923 & .16142 & .04477 & -.16678 & .02832 & 1.546 & 12 & .148 \\
\hline Pair 3 & $\begin{array}{l}\text { Power Endurance T2 - } \\
\text { Power Endurance T1 }\end{array}$ & 3.16667 & 5.71813 & 1.65068 & -.46646 & 6.79979 & 1.918 & 11 & .081 \\
\hline Pair 4 & Aerobic T2 - Aerobic T1 & 1.30769 & 1.64745 & .45692 & .31215 & 2.30324 & 2.862 & 12 & .014 \\
\hline
\end{tabular}

\section{A. Conclusion 1}

Thit 0.376 Sig. 0.713>0.05, then Ho is accepted, meaning that there is no influence from the method of running stair training to increase agility.

\section{B. Conclusion 2}

Thit 1,546 Sig. 0.148>0.05, then Ho is accepted, meaning that there is no influence from the running stair training method to increase power. 


\section{Conclusion 3}

Thit 1,918 Sig. 0.081>0.05, Ho is accepted, meaning that there is no influence from the running stair training method to increase power endurance.

\section{Conclusion 4}

Thit 2,862 Sig. $0.014<0.05$, then Ho is rejected, meaning that there is an influence from the method of running stair training to increase aerobics.

\section{DISCUSSION}

For the ability of agility, power, power endurance the increase that occurs is not significant This is because the principle of agility is the ability to change direction when running fast, this method of running stairs practice there is no principle of changing direction but going up the stairs so that Specifically there is no similar form for agility. Whereas in power capability, the change in increase that occurs is not significant. This is due to the fact that running stairs exercises are carried out by samples not explosively so that they do not support the increase in power according to the theory that if you want to increase exclusive power capability you must go through weight training specifically and aimed at maximum strength through intramuscular coordination of groups muscles (nueral activation) in order to produce more explosive power. This is certainly different from running stairs training which is dominant in applying dynamic strength training. Similar to the ability of power, even for power endurance the increase that occurs is not significant because it is more dominant to the endurance of the muscles, the ability becomes less than optimal. So that the impact of the change in improvement becomes insignificant even though in reality the practice of a difference of $1 \mathrm{~cm}$ is very valuable for a jumper when competing because this difference will determine who is the best as a Long Jumper for example.

As for Aerobic ability, it showed a significant change in the results of the running stairs training. This is due to the consistency of treatment which is also directed at training that is endurance. So that the aerobic capacity gets better.

Another finding is the excitement in training for student athletes when they get a new pattern with running stairs training to produce dynamic anaerobic and aerobic abilities such as those needed by many sports, especially the dominant speed, agility, and speed endurance. And, if you want to increase endurance can also be given running stairs training with a longer duration of each repetition or a longer distance or stairs. These materials encouraged stair use and had straplines explaining the health benefits of small amount of physical activity [19]. stair climbing significantly improved resting and exercises heart rates, perceived exertion, and dynamic balance performances in healthy seniors and may contribute to better overall fitness, reduced fall risk, and less perceived strain during daily life activities [20].

\section{CONCLUSION}

The implementation of running stairs training does not have a significant impact on increasing Anaerobic dynamic capacity but has a significant impact on increasing aerobic dynamic capacity. Therefore, the implementation of the running stairs training pattern that does not have an impact on increasing anaerobic average ability, it is advisable for trainers to provide running stairs training with loading models that are more gradual to anaerobic capacity, systematically according to periodization requirements and the demands of training objectives related to motion speed training in the form of speed and agility, dynamic power in the form of a jump movement, also power endurance, speed endurance, and endurance capacity. In order to produce scientific development in training that is more effective and efficient, this research can be developed through other studies or applications in sports that are more specifically dominant in physical abilities, such as the dominant speed sport (sport speed), power endurance dominant (sport power), or dominant endurance (sport endurance).

\section{REFERENCES}

[1] J.C. Barbero-Alvarez, V.M. Soto, V. Barbero-Alvarez and J. GrandaVera, "Match analysis and heart rate of futsal players during competition," Journal of sports sciences, vol. 26, no. 1, pp. 63-73, 2008.

[2] C. Castagna, R. Belardinelli, F.M. Impellizzeri, G.A. Abt, A.J. Coutts and S. D'Ottavio, "Cardiovascular responses during recreational 5-a-side indoor-soccer," Journal of Science and Medicine in Sport, vol. 10, no. 2, pp. 89-95, 2007

[3] F.M. Impellizzeri, S.M. Marcora, C. Castagna, T. Reilly, A. Sassi, F.M Iaia and E. Rampinini, "Physiological and performance effects of generic versus specific aerobic training in soccer players," International journal of sports medicine, vol. 27, no. 06, pp. 483-492, 2006.

[4] D.Z. Sidik, I. Imanudin and S. Mujiyanto, Dampak Pelatihan Harness Terhadap Peningkatan Kemampuan Dinamis Anaerobik dan Aerobik, 2010, pp. 1-22.

[5] J.R. Paffenbarger, J.B. Kampert, I.M. Lee, R.T. Hyde, R.W. Leung and A.L. Wing, "Changes in physical activity and other lifeway patterns influencing longevity," Medicine and science in sports and exercise, vol. 26, no. 7, pp. $857-865,1994$.

[6] D.R. Bassett, J.A. Vachon, A.O. Kirkland, E.T. Howley, G.E. Duncan and K.R. Johnson, "Energy cost of stair climbing and descending on the college alumnus questionnaire," Medicine and science in sports and exercise, vol. 29, no. 9, pp. 1250-1254, 1997

[7] S.F. Loy, L.M. Conley, E.R. Sacco, W.J. Vincent, G.J. Holland, E.G. Sletten and P.R. Trueblood, "Effects of stairclimbing on VO2max and quadriceps strength in middle-aged females," Medicine and science in sports and exercise, vol. 26, no. 2, pp. 241-247, 1994

[8] J. Ilmarinen, R. Ilmarinen, A. Koskela, O. Korhonen, P. Fardy, T. Partanen and J. Rutenfranz, "Training effects of stair-climbing during office hours on female employees," Ergonomics, vol. 22, no. 5, pp. 507 516, 1979.

[9] A.S. Leon, D. Casal and D. Jacobs, "Effects of $2000 \mathrm{kcal}$ per week of walking and stairclimbing on physical fitness and risk factors for coronary heart disease," J Cardiopulmon Rehab, vol. 16, pp. 183-92, 1996.

[10] W.L. Haskell, "Health consequences of physical activity: understanding and challenges regarding dose-response," Medicine Science Sports Exercises, vol. 26, pp. 649-60, 1994.

[11] M. Barinaga, "How much pain for cardiac gain?" Science, vol. 7, no. 276, pp. 1324-7, 1997.

[12] R.F. DeBusk, U. Stenestrand, M. Sheehan and W.L. Haskell, "Training effects of long versus short bouts of exercise in healthy subjects," The American journal of cardiology, vol. 65, no. 15, pp. 1010-1013, 1990

[13] M.H. Murphy and A.E. Hardman, "Training effects of short and long bouts of brisk walking in sedentary women," Medicine and science in sports and exercise, vol. 30, no. 1, pp. 152-157, 1998 
[14] J.R. Fraenkel and N.E. Wellen, How to Design and Evaluate Research in Education (Second edition). United States of America: Mc-Graw Hill,inc., 1993.

[15] L.A. Leger and J. Lambert, "A Maximal Multistage 20-m Shuttle Run Test to Predict VO2 max*," Eur. J. Appl. Physiol., vol. 49, pp. 1-12, 1982.

[16] B. Mackeinze, 101 Performance Evaluation Tests. London: Electric Word Plc., 2005.

[17] R. Wood, "3 Hop Test," 2008. [Online]. Retrieved from: http://www.topendsports.com/testing/tests/hop.htm. Access on 21 Januari 2016.
[18] R. Wood, "Multi Stages Jump Test," 2013. [Online]. Retrieved from: http//www.topendsport.com/testing/test/Multistagesjumptests.htm Access on 5 April 2013

[19] Middleton, "If Jogging is a joke, who should have the last laugh?," British Journal of Sports Medicine, vol. 34, pp. 143-144, 2000.

[20] L. Donath, O. Faude, R. Roth and L. Zahner, "Effects of stair-climbing on balance, gait, strength, resting heart rate, and submaximal endurance in healthy seniors," Scandinavian journal of medicine \& science in sports, vol. 24, no. 2, pp. e93-e101, 2014. 